\title{
Pobreza y beneficencia en el Toledo ilustrado. Creación de la Casa de Caridad
}

\author{
Ángel SANTOS VAQUero
}

\section{MENDICIDAD Y POBREZA}

La pobreza es producto del tipo de sociedad existente y de la mentalidad con que ésta afronta la distribución de la riqueza generada por ella misma. La injusticia social, la discriminación y el mal reparto del bienestar, el desprecio o infravaloración de ciertos oficios o profesiones que la propia sociedad necesita, el egoísmo, la avaricia, producen una sociedad desigual e injusta, obligando a llevar a algunos de sus individuos una vida mísera y desgraciada. Si a ello añadimos la vagancia, ociosidad y holgazanería, la picaresca o engaño para vivir a costa de la buena fe o ignorancia del prójimo, tendremos el cuadro completo de la indigencia. Así, la enorme cantidad de pobres, menesterosos, necesitados, indigentes, mendigos, pordioseros y vagabundos que llenaban los pueblos y ciudades de España tenía sus fundamentos en dos dispares razones: las derivadas de crisis económicas, paro estacional, años de malas cosechas con sus correspondientes periodos de hambre, deflaciones, decadencia industrial, etc., y los que teniéndolo por oficio, preferían vivir de la caridad pública o privada por comodidad o vagancia. Estos últimos alcanzaban en el siglo XVIII, según estimaciones de coetáneos, una cifra que oscilaba entre los 150.000 y los $200.000^{\prime}$. A este número hay que añadir los dos o tres millones de semidesocupados que vivian del favor personal o de la limosna encubierta de los poderosos, los buhoneros y los vendedores ambulantes ${ }^{2}$.

Palacio Atard, V., Los españoles de la ilustración. Madrid 1964, pág. 20.

2 Ibidem, pág. 20-22. 
En el marco de la pobreza hay que distinguir la mendicidad de la necesidad. Muchos mendigos no eran precisamente necesitados y por el contrario enormes cantidades de necesitados no pedían limosna públicamente, sino que solicitaban ayuda por medio de escritos a los ayuntamientos ${ }^{3} 0$ se presentaban ante el párroco o en los conventos para que les socorriesen en los momentos de necesidad. Estos eran los denominados «pobres vergonzantes".

Si bien las diversas crisis coyuntarales aumentaban el número de pobres, la mendicidad se hallaba muy arraigada en España. Sarrailh escribe: "... mendigos y vagos, plaga perpetua de España" ${ }^{4}$. Las calles de las distintas ciudades y pueblos del reino estaban infestadas de mendigos -incluidos los auténticamente pobres, los vagos, vagabundos y pobres fingidos- 10 mismo en época de crisis que de prosperidad. En el primer caso debido a que acudian para buscar ayuda y amparo en los hospitales, iglesias, conventos y casas nobles y en el segundo para aprovechar el bienestar reinante y vivir a costa de la caridad pública o privada mal entendida. Ninguno de ellos, en ningún momento, pensó nunca en buscar un trabajo honrado que le permitiese una estabilidad y un orden en su vida, preferían el vivir fácil y libre, sin sujeción a reglas, inmersos en la holgazanería.

\section{SOCIEDAD Y MISERIA EN EL TOLEDO ILUSTRADO}

La enorme cantidad de pobres existentes en los siglos XVI y xVII no decrece en el XVIII a pesar de la expansión económica que se produce en esta centuria en España, en consonancia con la línea seguida por Europa, porque «todavía al filo del año 1800 España era un país pobre, algo menos pobre, ciertamente, que en 1700; pero sus escasas riquezas se hallaban mal distribuidas y era ostensible el contraste entre la opulencia faraónica de unos pocos poseedores y la vida miserable del gran número de los desocupados» 5 .

Muy diversas eran las causas del número tan elevado de mendigos en el país: mal estado de la agricultura, escasa y anticuada industria, atrasados e inexistentes canales de comercialización, fácil limosna bendecida

\footnotetext{
3 Se pueden ver cantidad de ellos en el legajo Limosnas del A.H.M.T. (Archivo Histórico Municipal Toledo).

4 Sarrailh, José, La España ilustrada de la segunda mitad del siglo XVIII. México 1967, pág. 70

s Palacio atard, V., op. cit, pág. 18.
} 
y estimulada por la Iglesia, desprecio por los trabajos manuales, etc. Bernardo Ward pensaba que las dos últimas causas señaladas eran las determinantes del excesivo número de pordioseros y que había "tres vagabundos y holgazanes para un pobre verdadero; unos y otros piden limosna" ${ }^{6}$. Cabarrús, por el contrario, aseguraba que la mayoría de los mendigos de España lo eran por necesidad, por no hallar trabajo, y Campomanes dice que de los 140.000 mendigos que calculaba existían en el país, solamente 30.000 eran verdaderos necesitados ${ }^{7}$ (esta cifra supone el 21,4 por 100 del total calculado).

Toledo en el siglo XVIII era una ciudad decadente y con una sociedad desigual y de estructura arcaica. La mayor parte de la nobleza, abundante en épocas anteriores, huyó de Toledo cuando se llevó la corte a Madrid y la que quedó llevaba las riendas del gobierno municipal y provincial. Muy importante era el clero regular y secular. La clase media era la más numerosa (hidalgos, herederos o hacendados, profesionales liberales, funcionarios, tenderos y maestros artesanos), pero con escaso poder. En último lugar existía una clase baja constituida por oficiales, aprendices, sirvientes, criados y pobres de solemnidad. No obstante a muchos maestros artesanos difícilmente podríamos encuadrarlos dentro de la clase media, más natural sería incluirlos en la última categoría debido a su extrema probreza, teniendo que cesar en su trabajo y parar las labores por no poder adquirir materia prima, en especial los laneros y sederos, o quedar supeditados, como asalariados, a los encargos que les pudieran hacer los mercaderes, primeros y últimos poseedores del producto.

Con motivo de la matricula para el repartimiento de pan en 1737, sabemos que el vecindario de Toledo había descendido a 13.828 habitantes y además "tan infelices, que de 6.813 panes, que se señalaron diarios, (para el abasto de la población), el día que más, se consumían la mitad, por no tener los pobres con qué comprarlo" ${ }^{\text {. }}$.

Otra prueba del deplorable estado en que se hallaba la ciudad en este tiempo era que muchas casas principales y de comercio se hallaban cerradas y las que quedaban abiertas "arrendadas en tan ínfimos precios, que algunas, que setenta años ha rentaban 3.000 reales annuales, oy está

- WARD, B., Obra Pia y eficaz modo para remediar la misma de la gente pobre de España. Valencia 1750, pág. 36, citado por JiMÉNEZ SALAS, $M^{a}$, Historia de la asitencia social en España. En la edad Moderna. Madrid 1958, pág. 43.

7 Sarrailh, J., op. cit., pág. 81.

\& Memorial impreso enviado por el Ayuntamiento de Toledo a S.M. siendo corregidor el Marqués de Olías, el 26-08-1739. Legajo Seda número 1 (1500-1650). A.H.M.T. 
en ocho ducados de vellón" con el agravante de que no se solían cobrar, pues sus moradores abandonaban la ciudad sin efectuar el pago ${ }^{9}$.

Hacia mediados del siglo existían en la ciudad, según el Catastro de Ensenada, 800 pobres de solemnidad ${ }^{10}$, para una población de unos 25.000 habitantes $^{11}$; no obstante, en su Descripción sucinta, J. Porres da la cifra de 2.000 hombres entre pobres, vagos y holgazanes ${ }^{12}$, lo que daría una proporción, en una población de 19.320 habitantes ${ }^{13}$ del 10,3 por 100 , si bien la mayoría no eran vecinos de ella, sino gentes que venían de fuera.

La Mancha era una comarca que generaba enorme pobreza y de ella procedían multitud de mendigos que sólo se mantenían de las limosnas; así se pone de manifiesto en diversos consistorios a lo largo del siglo. Esta plaga producía bastantes raterias y actos delictivos que las autoridades de la ciudad trataban de reprimir y evitar publicando bandos donde se ordenaba la salida de todos los pordioseros forasteros so pena de fuertes castigos; pero escasa eficacia debían tener tales órdenes pues son multitud las que se repiten a lo largo de la centuria ${ }^{14}$.

A finales de siglo, en 1771, se contaron en Toledo 839 pobres, (201 hombres y 638 mujeres, viudas y solteras). En esta cifra no se incluirían los vagos y mendigos que no tuviesen residencia fija y no se hallaran matriculados en las diferentes parroquias de la ciudad, ni las mujeres casadas ni los niños. (El cuadro de los pobres existentes en Toledo en 1771, distribuidos por parroquias, se inserta en la página siguiente) ${ }^{15}$.

Este estado de pobreza y deterioro se hace patente en las Actas de su Ayuntamiento. El corregidor, en la sesión de 16 de enero de 1784, expone el mal estado en que se hallaba la ciudad. El jurado D. José Ruiz Ledrado manifiesta en su intervención, que el vecindario se halla en deplorables condiciones y «que apenas se encuentra quien tenga lo necesario para el diario y preciso sustento" ${ }^{16}$. Los comisionados para asuntos

- Ibidem.

10 A.H.P.T. Archivo Histórico de Protocolos de Toledo. Respuesta a la pregunta número 36 del Interrogatorio General de la letra A, H-680, Catastro de la Ensenada.

11 Respuesta a la pregunta número 21 del Interrogatorio General del la letra A, libro H-680, Catastro de la Ensenada.

12 Porres Martin-Cleto, J., "Una descripción sucinta de Toledo en 1767 y 1768 ", en Anales Toledanos, vol. V. Toledo 1971, págs. 131 y 132.

13 Ibidem, pág. 119.

14 Archivo Histórico Municipal de Toledo (A.H.M.T.). Ver Legajo Pobres.

15 A.H.M.T., Libro Fondo de Legos. Año 1771, tomo 9, número 27 a. Pobres 1771 (hombres). Libro Fondo de Legos. Año 1771, tomo 10, número 27 b. Pobres viudas y solteras (mujeres).

16 A.H.M.T., Libro manuscrito de Actas del Ayuntamiento de Toledo de 1784, número 206. Acta de la sesión de 16 de enero. 
de policía, presentaron un informe y entre sus conclusiones exponen que les es "muy doloroso ver de día en día crecer la decadencia de esta población el ruidoso (sic) estado de sus artesanos y la mendicidad a que la ha reducido el tiempos ${ }^{17}$.

AÑO 1771: POBRES EN TOLEDO

\begin{tabular}{lrcr}
\hline \multicolumn{1}{c}{ Parroquias } & Hombres & $\begin{array}{c}\text { Mujeres (viudas } \\
\text { y solteras) }\end{array}$ & Total \\
\hline San Miguel & 16 & 49 & 65 \\
Sta. M. Magdalena & 20 & 50 & 70 \\
San Bartolomé & 17 & 33 & 50 \\
San Martín & 4 & 4 & 8 \\
San Cebrián & 3 & 18 & 21 \\
San Pedro & 6 & 33 & 39 \\
San Román & 13 & 58 & 71 \\
San Ginés & 4 & 20 & 24 \\
San Juan Bautista & - & 6 & 6 \\
San Justo & 11 & 35 & 46 \\
San Salvador & 1 & 5 & 6 \\
Santo Tomé & 33 & 67 & 100 \\
Santiago & 13 & 56 & 69 \\
San Andrés & 9 & 21 & 30 \\
San Vicente & 2 & 12 & 14 \\
San Antolín & 3 & 22 & 25 \\
Santa Leocadia & 14 & 23 & 37 \\
San Nicolás & 10 & 49 & 59 \\
San Cristóbal & 3 & 8 & 11 \\
San Lorenzo & 10 & 42 & 52 \\
San Isidoro & 9 & 27 & 36 \\
\hline TOTAL & 201 & 638 & 839 \\
\hline
\end{tabular}

A pesar de todas las medidas de beneficiencia y disposiciones legislativas, el número de pobres y mendigos no disminuía. La Iglesia, con su política de ayuda indiscriminada e interesada a los mendigos y vagabundos (en caso distinto se vería muy disminuida su misión en este mundo e injustificado el acaparamiento de tanta riqueza, cuya posesión sólo tenía razón de ser si se destinaba a socorrer una abundante grey de pobres auténticos o profesionales), contribuía en gran medida a la existencia de una caterva de pordioseros y fomentaba la ociosidad.

17 Ibidem, Acta de la sesión de 19 de enero. 
Era la Iglesia la única institución que, como tal, satisfacía de forma sistemática las necesidades de beneficiencia durante los siglos XVI y XVII, con numerosos y amplios repartos de pan y limosnas en los palacios episcopales, en las catedrales y grandes abadías, además de las numerosas hermandades y cofradías creadas para tal menester, y aunque en el XVIII se inicia una labor benéfica y de asistencia social por parte del Estado, no por ello dejó aquella de ser uno de los pilares en esta actividad caritativa. Con ello mantenía su popularidad y la adhesión y fe, aunque sólo fuese superficial, del pueblo.

En Toledo sobresalen dos instituciones eclesiásticas en la distribución de limosnas: el cabildo catedralicio y la dignidad arzobispal. El primero tenía instituidas una serie de ellas que recibían distintos nombres y comprendían diversas finalidades. La del «Panecillo del Claustro", encargada de repartir 600 fanegas de trigo procedentes, a partes iguales, de la dignidad arzobispal, de la fábrica y obra de la catedral y del cabildo. Comenzaba su repartimiento el primer día del año y se continuaba diariamente hasta agotar el último kilo de harina ${ }^{18}$. La de "doncellas pobres y de buen linaje" que dejara D. ${ }^{a}$ Teresa de Haro. La que instituyera $D .^{\circ}$ Juan López de León, canónigo, para mujeres indigentes. La "de los mandatos» para viudas o doncellas nobles, que importaban cada una más de 100 reales y todas juntas algunos millares de reales. La que dotaba a mujeres por casar o entrar en religión llamada de "don Alfonso de Fonseca o de la Suerte", que suponía de 30 a 40.000 reales. La de "Capuces" que estaba al cargo de los canónigos, instituida sólo para pobres vergonzantes y que pasaba de 32.000 reales al año por quinquenio. Además dependían de él varias instituciones de beneficiencia: el Hospital de Santa Cruz, el nuncio, el hospital de Ntra. Sra. de la Misericordia, el de San Juan Bautista o del cardenal Tavera o de Afuera y los colegios de Santa Catalina e Infantes.

El arzobispado distribuía, además de las dádivas que cada prelado estimaba oportuno, desde tiempo inmemorial, la limosna denominada del "Mandato", con la que mantenía a 30 pobres diariamente durante todo el año. Se les daba un plato de cocido, incluida la ración de carne correspondiente (1/2 libra de carnero), pan ( 1 libra) y vino $\left(1 / 2\right.$ cuartillo) ${ }^{19}$.

is Según Porres, J. en su “Descripción sucinta...», op. cit., pág. 132, en 1770 se acabó el 29 de marzo y en los 4 años antecedentes, en el mes de abril, siendo que antes duraba todo el año. Esto prueba la enorme necesidad y miseria de estos años en Toledo.

${ }_{19}$ Sobre el tema ver GIL Calvo, J., La Compañia de Jesús en la $H^{\mathrm{a}}$ de Toledo. Toledo 1979, págs. 107-108 y 157-158. Ver también PorRES, J., «Descripción sucinta...”, op. cit., pág. 132. 
Se estimaba que con estas y otras limosnas más que daban la Iglesia toledana, su Eminencia el cardenal y las que otorgaban algunos conventos y eclesiásticos particulares, se sobrepasaba la cifra de un millón de reales al año las que se concedian en Toledo ${ }^{20}$.

A fines del siglo XVII, el cardenal Portocarrero mantenía en Toledo a más de 4.000 pobres a su cuenta ${ }^{21}$. Ya en el siglo xVIII, desde la época del cardenal Diego de Astorga y Céspedes (1720-1734) estuvo funcionando la "limosnería", un negociado específico introducido en las oficinas de rentas de la Mitra ${ }^{22}$. Los sucesivos prelados no escatimaron recursos para ayudar a las necesidades. Así, D. Luis Fernández de Córdoba (17551771), cardenal primado de Toledo, pretendió organizar e institucionalizar la ayuda, que ya había sido sistematizada anteriormente por el cardenalinfante D. Luis de Borbón, llegándose a emplear en limosnas 1.500 .000 reales a mediados de la centuria ${ }^{23}$. El proceso alcanzará su máxima expresión con el cardenal Lorenzana (1772-1800), llamado el upadre de los pobres", como así reza en el epitafio grabado en su tumba en la basílica de Santa Cruz de Jerusalén, en Roma ${ }^{24}$.

\section{MEDIDAS CONTRA LA POBREZA EN TOLEDO}

Los ilustrados, en especial a partir del reinado de Carlos III, introdujeron en España una serie de ideas nuevas, que en realidad ya habian aflorado en los últimos decenios del siglo XVII, en el ámbito económico, científico, político, filosófico, religioso y benefico-asistencial, que irán poniendo en práctica paulatinamente en unos casos, quedando en otros sólo en simples deseos o meros propósitos.

Las ideas de eficacia y productividad borbónicas chocaban frontalmente con la inmensa multitud de vagos y mendigos que pululaban por el país; por eso, la lucha contra la vagancia y los pobres fingidos representa uno de los pilares reformadores de los ilustrados. Para acabar (eso pretendian) con la ociosidad se tomaron diversas medidas: se trató de

\footnotetext{
20 Ver Porkes, J., op. cit., en nota anterior, pág. 134.

2) Ver CAMPOY, José $M^{a}$, "La sede toledana en el siglo XVIII», Toletum, año X, oct.-dic., 1928, número 36-37, R.A.B.A.C.H.T. Toledo, pág. 186.

22 Gutiérrez Garcia Brazales, Manuel, Francisco Antonio de Lorenzana, el Cardenal llustrado de Toledo, Simposio «Toledo llustrado" II. Toledo 22-24 marzo 1973, pág. 18.

23 Ver GIL Calvo, J., Op, cit., pág 108.

24 Para conocer el nombre de otros caritativos obispos y sus diócesis respectivas, ver $\mathrm{SA}_{\mathrm{A}}$ Rrailh, J., Op. cit., págs. 137-39. Ver también TAPIA Ozcáriz, Enrique de, Carlos III y su época. Biografía del siglo xvIII. Madrid 1962, pág. 373.
} 
cambiar la mentalidad de la nobleza con respecto a la industria y al comercio, se dignificaron los oficios mecánicos; se procuró ampliar la educación y cambiar el sistema de enseñanza; se dictaron numerosas ordenanzas contra los vagos, a los que, por medio de levas, se les aplicaba al servicio del ejército y a la marina, siempre que fuesen aptos para las armas; se recogió a los niños, viejos, disminuidos psíquicos e imposibilitados en hospicios u otras instituciones benéficas, donde se les atendía física y religiosamente, a la vez que se trataba de dignificar su vida haciéndoles sentirse útiles a si mismos y a la sociedad con un trabajo digno y adecuado a sus posibilidades; etc.

Medidas especiales hubo de dictar el corregidor y Ayuntamiento de Toledo para paliar la invasión de mendigos que acudían a la ciudad buscando amparo a sus necesidades desde las zonas más deprimidas de la Mancha y Andalucía, y de Madrid. Los motivos de esta irrupción masiva no los da D. Juan Ortiz de Zárate, regidor del Ayuntamiento toledano, en su intervención en la sesión de 3 de septiembre de 1721 al decir que «haviendo oi dado motivo al maior número de los forasteros, la providencia que en la villa de Madrid se a dado de instituzión de hospicio en donde se les recoxe de cuio benefizio uyen, por andar bagando por las repúblicas oziosamente". En esa misma sesión se queja de la invasión que sufre Toledo de mendicantes expresando "que bien notoria es la multiplicidad de pobres mendigos que ai en esta ciudad, atraídos los más de otras poblaciones al veneficio de la diaria limosna que se distribuía por la caridad christiana de diferente fundaciones y comunidades..." haciendo notar que tal multitud de pobres mendigos molestaban en los templos, perjudicando la piedad de los fieles realizando ilícitos comercios y daños a la población. Opina que esta situación debe ser corregida por el Ayuntamiento "practicando si fuera combeniente la (providencia) que en otros tiempos a usado de hazerse rexistro de las personas naturales y vezinas desta ciudad que por este medio procuran su alimento lexitimamente respecto de hallarse ymposibilitados de buscar otro a quienes se les dé su lizencia para poder pedir en la ciudad", y que los forasteros, pasado un corto tiempo, salgan de ella y vayan a sus respectivos obispados o lugares de nacimiento, donde se les atienda ${ }^{25}$.

25 A.H.M.T., Cuadernillo semigrueso con el título: "Año de 1721. Autos de Providencia echos en birtud de Acuerdo del IImo. Aiuntamiento desta cludad y por el Sr. Corregidor y cavalleros nombrados para el reconocimiento de los pobres, así naturales de esta ciudad como fuera aparte que tubieren necesidad de pedir limosna legitimamente se las conceda para dicho finm, legajo Pobres. 
Un día después de la sesión consistorial, es decir, el 4 de septiembre, el Marqués de Olías, corregidor de Toledo, mandó se pregonase un bando ordenando que todas las personas que necesitasen pedir limosna para mantenerse, se presentanse en el Ayuntamiento en el término de ocho días a partir de la fecha del auto, para que se les diese licencia, so pena de veinte días de cárcel y destierro de la ciudad. Todos los forasteros menesterosos deberían abandonar Toledo en el mismo término de ocho días ${ }^{26}$.

Otra voz acorde con la de D. Juan Fco. Ortiz de Zárate vuelve a oírse en el Ayuntamiento de la ciudad imperial de 13 de julio de 1722 . En esta ocasión es el alcalde mayor, don Francisco de Pinedo el que manifestó "que a causa de huirse muchos pobres del ospicio que para recoxerles ai en la corte y haberse benido desta ciudad, y otros muchos de los lugares de la mancha. Ay gran suma de gente que sólo se mantienen en Toledo sin más exercicio que el de pedir limosnas, sin embargo, de la providencia dada para que ninguno que no tenga lizenzia para pedir lo pueda hacer...". A su vez solicita acción al Ayuntamiento para poder tomar las medidas oportunas, dado el perjuicio que la invasión de la ciudad por parte de mendigos sin licencia reporta a la républica y a los pobres de esta ciudad. En esa misma sesión se tomó el acuerdo de dar un bando reiterando el del 4 de septiembre de $1721^{27}$.

La ineficacia de estas medidas y disposiciones queda patente con las quejas que se siguen oyendo sobre la invasión de mendigos que sufre Toledo, como la de D. Cristóbal de Vargas, el 30 de julio de $1723^{28}$ y los bandos que continúan emitiendo para paliar tal situación.

Conociendo que es en las tabernas y mesones donde solian pasar gran parte del día y albergarse la mayoría de mendigos y vagos, el 2 de mayo de 1748, D. José García Peñalosa, alcalde mayor y teniente corregidor, en ausencia del corregidor, marqués de Espinardo, y por proposición del Cabildo de Jurados, ordena dar un bando del siguiente tenor:

«... ninguna persona desde la hora de las once en el verano y de las diez en el invierno, pueda con armas o sin ellas andar de noche por esta ciudad, pena de diez ducados y quinze días de cárcel por la primera vez, y por la segunda, a el arvitrio de su merced. Que todas las tabernas estén cerradas precisamente a dicha hora de las diez, en todos los tiempos, y

26 Ibidem, Auto de 04-09-1721. (El pregonero voceó el bando en los lugares acostumbrados de: Pza. del Ayuntamiento, Pza. Mayor, Cuatro Calles, Zocodover y Pza. de Santo Tomé).

${ }_{27}$ Ibidem, Ayuntamiento de 13-07-1722.

28 Ibidem, Ayuntamiento de 30-07-1723. 
no tengan en ellas mesas, vancos, ni otros asientos para jugar ni sentarse los que entran a vever, pena a los taverneros que contravinieren a uno u otro de quatro ducados de vellón por la primera vez, por la segunda ocho y quinze días de cárcel y por la tercera se les aplicara a servir a S.M. por seis años en uno de los presidios de África; y a los que estubiesen sentados y detenidos en dichas tavernas, se les ympone la pena de dos ducados de vellón.

Que todas las personas así hombres como mugeres que con color de pobres andan vagando en esta ciudad, salgan de ella precisamente en el término de tres días exceptuándose, sólo, los que sean naturales desta ciudad, o que ayan residido en ella de diez años a esta parte, pero estos acudiran al IImo. Ayuntamiento desta ciudad para que como naturales y residentes del tiempo expresado; se les dé la lizencia que es estilo para que no se les ponga embarazo en su residencia con apercivimiento de que el que no saliese desta ciudad en el preferido (sic) término de tres días o no tubiese la dicha lizencia se les asegurara a esta Real Cárcel y conducirá por vago, siendo hombre, a uno de dichos presidios por tiempo de quatro años, y siendo muger se le pondrá a verguenza pública y con efecto se le echara desta suerte desta ciudad: entendiéndose 10 mismo con los que aunque no piden limosna no tengan empleo, $u$ otro destino, y se ygnore el motivo y causa de su residencia en esta dicha ciudad.

Que se notifique a todos los mesoneros desta ciudad, que todas las noches pongan en poder del cavallero jurado del distrito de la parroquia en que cada uno tubiese su mesón, lista de todos los huéspedes que en el día ayan entrado en él, con expresión de nombres, apellidos, de donde vienen y armas que tubiesen, lo que cumplan, pena de diez ducados de vellón por la primera vez y por la segunda al arvitrio de su merced" ${ }^{29}$.

No obstante, y a pesar de todos los esfuerzos realizados, en la segunda mitad del siglo xVIII los mendigos seguían llenando las calles de las ciudades españolas, aparte de los recogidos en las instituciones benéficas. Confirma esta afirmación el que ante la avalancha de pobres pedigüeños en Toledo, se elevan peticiones y se den bandos similares a los vistos anteriormente en 1750, 1753, 1754, 1766, 1772, 1776 y 1780.

No sólo la administración local llevaba a efecto medidas contra la holgazanería, también éstas emanaban de la central. En 1749, por Real Orden, se prohibió la entrega de limosnas. En ese mismo año se ordenó a los intendentes y corregidores que no consintieran en sus territorios gente ociosa ni vagubundos, aplicándolos a trabajos útiles al pueblo o destinándoles al servicio de las armas y que obligasen a los inútiles para el trabajo o milicia a recluirse en casas de misericordia. Ordenanzas simi-

29 A.H.M.T., Cuadernillo pequeño cuyo título es: "Años de 1748, 1750 y 1753 . Sobre pobres que handan pidiendo limosna por la ciudad". Leg. Pobres (Por las notificaciones que vienen añadidas al documento, podemos saber que en Toledo había en esa fecha 12 mesones). 
lares se repitieron en $1775,1782,1784$ y 1789 . En 1778 se dio orden de recluir a todos los vagabundos en su lugar de origen o en la capital de la diócesis ${ }^{30}$. Asimismo, se dieron numerosas disposiciones en relación a los pobres y mendigos.

Conocedora la administración central de la poca efectividad obtenida en la recogida de vagos, pordioseros y ociosos, dado el poco vigor de las justicias, lo que había producido un aumento de los robos y demás formas delictivas contra la sociedad, se emite Real Cédula de S. M. dada en Valladolid a 5 de marzo de 1787 por acuerdo de la Real Chancillería «sobre persecucción y captura de malhechores, vagos, gitanos y gente sospechosa". Se trata de exterminar a los enemigos de la sociedad y proporcionar tranquilidad pública, reduciendo a via civil y cristiana, a todos aquellos contra los que va dirigida; y obligándolos a tener domicilio y oficio fijos. Con el fin de obtener resultados positivos y duraderos, la Real Cédula endurece la postura real y ordena que se de cuenta de aquellos corregidores y alcaldes que no cumplan y ejerciten lo ordenado por su Majestad ${ }^{31}$.

De esta serie casi ininterrumpida de disposiciones y ordenanzas, tanto municipales como del gobierno central, se infiere que la efectividad de las mismas fue casi nula a pesar de su buena voluntad, debido a la desidia general, la falta de medios para llevar a cabo una labor tan ardua y costosa, la decadencia del país, las limosnas fáciles e indiscriminadas y, lo que es peor aún, la conciencia social de rechazo de los trabajos manuales. Esta mentalidad de la sociedad no va a cambiar hasta que la burguesía logre introducir plenamente en ella sus postulados, consiguiendo que las arcaicas estructuras sociales se transformen y el sentimiento de trabajo y riqueza no sea compatible con el de hidalguía y honorabilidad.

\section{CREACIÓN DE LA REAL CASA DE CARIDAD DE TOLEDO: DIFICULTADES}

Un punto crucial para llevar a cabo, momentáneamente, la política de erradicación de la ociosidad y de la pobreza, además de aplicar al vagabundo al trabajo, era la creación de hospicios donde recluir y asistir al

30 Ver. Vicens Vives, J., Manual de Historia Ecónomica de España. Barcelona 1959, novena edición, 1972, págs. 456-58 y ANES, G. "El Antiguo Régimen: los Borbones", tomo IV de la H." de España. Madrid, Alfaguara, 1975, págs. 153-56.

${ }^{31}$ A.H.M.T., Cuadernillo manuscrito con el título: "Año de 1787. Real Cédula de S.M. sobre persecución y captura de Malechores, Vagos, Gitanos y gente sospechosa. Dada en Valladolid a 5-3-1787. Es acuerdo de la Real Chancillería". Legajo Vagos. 
auténtico necesitado y recoger y amparar a los desvalidos. Sin embargo, no todos los ilustrados eran partidarios de la centralización de la beneficencia y de la recogida de mendigos y pobres en hospicios, asilos $u$ hospitales, aunque sí todos coincidían en la necesidad de que se les proporcionase trabajo, enseñándoles un oficio adecuado a sus condiciones.

La administración borbónica se apoyó en la Iglesia para llevar a cabo su labor benéfica, especialmente en los obispos y cardenales ilustrados. Los motivos son obvios: prestigio moral entre la sociedad en general y entre el pueblo llano en particular; infraestructura apropiada y extensa; riqueza suficiente y función caritativa como rasgo distintivo. En una palabra, las posibilidades de la institución eclesiástica eran inmensas tanto desde el punto de vista moral como material. Tampoco es de despreciar la idea de que el Estado pretendiera minar el poder de la Iglesia desposeyéndola de la exclusividad benefactora con la que mantenía su autoridad, reputación, crédito e influencia ante el pueblo y controlar parte del capital eclesiástico, fijando obligatoriamente lo que antes era en su mayor parte potestativo y aleatorio.

Carlos III impulsó con vehemencia la creación de hospicios y en 1766 se interesó por la creación de uno en Toledo. Este interés vino definido por dos principales motivos: uno caritativo y otro pragmático. Este último vendría dado ante la necesidad de desalojar Madrid del exceso de mendigos que acudían por el atractivo de la corte y disponer una "ciudad hospicio" para su recogimiento, y Toledo era un lugar idóneo por su proximidad geográfica ${ }^{32}$. Otro motivo podría venir dado por el deseo de erradicar las alteraciones de orden público de la corte debido al gran número de mendigos y vagabundos que había en Madrid, lo que conllevaba el peligro de manipulaciones políticas, dada la facilidad con la que se podía manejar a esta muchedumbre y así introducir elementos de confusión y desorden en la sociedad.

Por Real Orden de 6 de septiembre de 1766, comunicada al cardenal de Toledo y al deán y cabildo de la catedral, Carlos III manifestó que sería de su agrado la creación de un hospicio en la ciudad, destinando para su logro las obras pías y fundaciones que, con bula pontificia o sin ella, fueran aplicables ${ }^{33}$. Después de diversas consultas y conferencias entre

32 Ver LÁzaro Fuentes, J., H. de la Real Casa de Caridad de Toledo, Simposio aToledo llustrado", (Toledo 22.24 marzo 1973), vol. Il, Publicaciones del Centro Universitario de Toledo, pág. 73. Otro motivo que aduce este autor es el de «neutralizar de algún modo las riquezas de la Diócesis más extensa de España», al considerar que si dichas riquezas se empleaban en la caridad pública, no podían alentar la oposición al absolutismo real y sus decisiones.

${ }_{33}$ Archivo Diocesano de Toledo (A.D.T.). Copia de una carta del Cabildo de la Catedral a 
el cardenal, cabildo y Ayuntamiento, el citado proyecto no vio la luz debido a las dificultades que expuso el Cabildo catedralicio en la forma y conveniencia de aplicar el capital de algunas obras pias de su patronazgo. Entre otros inconvenientes aducía que cada limosna, en su fundación tenía un destino determinado que no podía alterarse sin perjudicar a aquellos a quienes iba destinado ni cambiar los deseos e intención de sus fundadores. De todas las rentas de obras pías, fundaciones y limosnas pertenecientes a su patronato, el Cabildo acordó donar a la futura Casa de Caridad aquellas que juzgaron aplicables (las menos numerosas y de menor cuantía) y que ascendian a un valor de 12.500 reales aproximadamente, sin contar las 600 fanegas de trigo del "Panecillo del Claustro", que también acordaron conceder, ni las raciones que diariamente sobrasen de las 30 del Mandato, después de reservadas las precisas para clérigos, peregrinos y pasajeros a quienes estaba destinada tal limos$\mathrm{na}^{34}$.

La resistencia del Cabildo catedralicio a ceder ciertas memorias y obras pías, como eran las memorias de Capuces y las de Dotes, implica un enfrentamiento frontal entre los poderosos canónigos y la Corona, similar al que por entonces mantenían aquellos respecto a la dotación de los curas rurales con las rentas beneficiales.

Por la necesidad imperiosa de reducir el número de pordioseros en Madrid, los fiscales del Real Consejo estudiaron el problema y decidieron que sería conveniente la creación de un hospicio en Toledo por su situación geográfica próxima a la capital y por las posibilidades de infraestructura asistencial de que disponía la ciudad Imperial; pero quizás ante las dificultades que presentaba la postura de los canónigos de la catedral toledana, se envió en esta ocasión la notificación de lo sucedido al Ayuntamiento y no a las autoridades eclesiásticas, para que fuese aquél quien tomara la iniciativa y pusiera el proyecto en marcha, pidiendo la colaboración de la Iglesia.

En la sesión del Ayuntamiento de 9 de octubre de 1769 se vio una carta-orden de fecha 26 de septiembre del mismo año, firmada por D. Ignacio de Ygareda, Secretario de Cámara del Rey, y del Real Consejo de S.M., con la respuesta dada por los fiscales del mismo sobre la for-

D. Miguel de Muzquiz, de fecha 12-01-1775. Leg. Casa de Caridad. También Libro manuscrito: Rentas Fijas. $1 .^{\circ}$ Real Casa de Caridad. Archivo de la Diputación Provincial de Toledo (A.D.P.T.).

${ }_{34}$ Copia de la carta indicada en la nota anterior. Para una mejor comprensión de la actitud de los canónigos, se deberá comparar las limosnas que pertenecían al Cabildo (ver apartado "Sociedad y miseria en el Toledo ilustrado"), con las que vemos aquí donadas. 
mación de una Hermandad para un hospicio en Toledo. El informe dado por los fiscales del Real Consejo de Castilla era favorable a la erección del mismo, entre otros motivos porque «si llegase a establecerse escusaría la venida de muchos mendigos a la Corte y descargaría de su manutención a los Hospicios de Madrid y San Ildefonso". Por ello solicitaban la mayor brevedad en el tratamiento de su creación y se informase rápidamente al Consejo sobre el «sitio, fondos y limosnas con que puede contarse para este nuevo establecimiento". En este Ayuntamiento se resolvió que el corregidor, de acuerdo con los «comisarios» que nombrase el cardenal, los señalados por el Cabildo catedralicio y los comisionados por la ciudad, que lo fueron D. Eusebio José García Toledano, regidor, y D. Juan Antonio Valera y Bustos, jurado, tratasen en una reunión sobre la fundación del hospicio teniendo en cuenta las reglas propuestas para el de Madrid y el de S. Fernando ${ }^{35}$.

La ciudad se puso en marcha con inusitada actividad y se celebraron diversas reuniones en casa del corregidor.

En el Ayuntamiento, el 11 de noviembre de 1769, D. Eusebio José García Toledano, antes de presentar una solicitud y a fin de predisponer a un voto favorable a los ediles, expuso que Toledo siempre había sido pródiga con el rey, tanto en guerra como en paz y que no había escatimado en los gastos para festejar las juras, casamientos y natalicios de los príncipes, realizando funciones públicas con el mayor honor, ostentación y profusión, como se deben a personas de tan alto relieve, y que ahora, para el fin caritativo propuesto por S.M., a través de su Real Consejo, debe hacer la ciudad todo lo posible en recabar los medios necesarios para crear, erigir y mantener el mencionado hospicio.

El proyecto, que presenta al Ayuntamiento D. Eusebio García Toledano, sobre de dónde obtener capital y renta para el fin propuesto, se cimenta en dos pilares: los despoblados de Renales y Villamucén y la renta del aguardiente y licores. En lo que respecta a los primeros, propone que, al tener el Ayuntamiento de Toledo estos dos despoblados en comunidad de pastos con la villa de Fuensalida, se solicite al Real Consejo se conceda dividirlos proporcionalmente, y la parte correspondiente a esta ciudad, ya que sus vecinos no usan de ellos ni de sus pastos por la distancia de cinco lenguas a que se hallan, se subaste cy el producto se aplique a las rentas propias del Real Hospicion. Sobre la renta del aguardiente y

35 A.H.M.T. Libro de Actas del Ayuntamiento de Toledo de 1769, número 191. Acta de la sesión de 9 de octubre. 
licores, solicita se pida al R. Consejo se "aplique a la piadosa Real obra del Hospicio la cantidad de 500 ducados anuales" ${ }^{36}$.

Dos días después se celebró otra sesión. Hubo un debate sobre la propuesta anterior y se acordó por mayoría aceptar la proposición de D. Eusebio. La ciudad mandó se midieran las fanegas de los despoblados antedichos, se citase a la villa de Fuensalida y se hiciese la división que se pedia para pastos, poniéndose cotos para que la parte que correspondiera a Toledo se pudiese subastar ante el alcalde de la jurisdicción de dichos términos.

Por Real Provisión de 25 de octubre de 1770 se aprobó la consignación hecha por Toledo de 500 ducados anuales en el sobrante de la renta del aguardiente para el establecimiento del hospicio. Asimismo, el Real Consejo admitió la proposición sobre los despoblados de Renales y Villamucén y estableció que "para que tenga efecto con la devida formalidad, se comete al Sr. Corregidor que con citación y audiencia instructiba de los Procuradores Síndico y Personero de dicha villa de Fuensalida y de los de esta ciudad como únicos pueblos comuneros en los referidos pastos les haga dividir y aplicar a cada pueblo la parte correspondiente y medir y amojonar lo que tocase a Toledo y regular el número de cavezas de ganados que pueden mantenerse en ella y lo que corresponda pagarse por cada una". El Corregidor mandó hacer requisitoria para que en el término de seis dias se reuniesen los interesados y se ejecutase lo ordenado por S.M. y señores de su Real Consejo de Castilla ${ }^{37}$.

Puede constatarse por lo expuesto hasta el momento, la buena disposición y ánimo del Ayuntamiento de Toledo para atender con prontitud y entrega a la creación de una casa de caridad en la ciudad. No sería por culpa de los representante del municipio por lo que el hospicio tampoco en esta ocasión llegó a materializarse. Fueron otras las causas que hicieron imposible su creación, en especial la política del cabildo catedralicio, que no quiso ver disminuida su capacidad de independencia de donación de limosnas, pues ello redundaría en la merma de su prestigio, crédito y ascendiente social ante el pueblo toledano. Así lo prueba su pertinaz resistencia y negativa a ceder a la proyectada Casa de Caridad otras rentas de obras pías, fundaciones y limosnas que las ya expresadas en 1754 y reiteradas en $1766^{38}$.

36 Ibidem, Acta de la sesión de 11 de noviembre.

${ }^{37}$ A.H.M.T., Libro de Actas del Ayuntamiento de Toledo de 1770, número 192. Acta de la sesión de 12 de noviembre.

38 A.D.T, Ver carta enviada por los canónigos a D. Miguel de Muzquiz en 1775. Leg. Casa de Caridad. 
Al morir D. Luis Fernández de Córdoba le sucede en la sede Primada el cardenal Lorenzana. Toma posesión de la archidiócesis por poderes, a través del deán de la catedral $D$. Aurelio Benito, pues se hallaba todavía en Méjico. Llega a Cádiz el 18 de julio de 1772 y entra solemnemente en la ciudad imperial el 3 de octubre del mismo año. Pronto conoce la intención real y el proyecto de hospicio en Toledo. Con su carácter piadoso y emprendedor, su espíritu ilustrado y su fuerte personalidad, decide con presteza llevar a efecto su fundación y escribe al rey el 26 de mayo de 1773 indicándole que si era de su mayor agrado, él y su cabildo se harian cargo de la creación y conservación del referido hospicio.

Por iniciativa del propio cardenal, el rey aprueba, con fecha 14 de junio del mismo año, el que sea el referido prelado y su cabildo los encargados de tal menester; deja en el propio arzobispo el cometido de "avisar las providencias que se necesiten de parte de S.M. para auxiliar los medios que se juzgan más bien ordenados y dirigidos a un fin tan loable» y que por parte de la corporación municipal asista a las juntas el procurador general y un regidor ${ }^{39}$.

Esta nueva ordenanza referente a la composición de la Junta de creación y conservación del hospicio va a producir choques de intereses político-institucionales en el Ayuntamiento, que sólo se resolverán con la intervención del Consejo Supremo de Castilla. La representación municipal en la Junta del proyecto de hospicio de 1769 no produjo enfrentamientos debido a que dejaba en manos del corregidor la presidencia de la misma y permitía al Ayuntamiento la elección de sus vocales; pero con las normas presentes, el corregidor quedaba marginado y se introduce un elemento de discordia al determinarse que debían asistir el procurador general y uno de sus capitulares. El problema se suscita a la hora de determinar quién se entendía como procurador general, si el Cabildo de jurados o el Procurador síndico personero.

El cabildo de jurados del Ayuntamiento de Toledo presentó un informe en el que aducía que desde su creación por Juan II en 1422, con los mismos privilegios y honores, facultades y ordenanzas que por entonces tenía el de Sevilla, y desde entonces por la costumbre inveterada que se ha seguido, en él se hallaba radicado el oficio y voz de procurador síndico general del Común de Toledo, por lo que se extrañaban de que se dudase de sobre quién debería recaer el nombramiento de procurador general

39 A.H.M.T. Libro de Actas del Ayuntamiento de Toledo de 1773, número 195. Acta de la sesión de 21 de junio, donde se vio la Real Orden de 14 de junio, dirigida al Corregidor de Toledo. Ver también el Libro manuscrito: Rentas Fijas, número 1. Real Casa de Caridad. A.D.P.T. 
para la Junta del hospicio, pues el cargo de síndico personero fue creado por Real Orden de 1766 y no se abolió ni dejó en suspenso el oficio de procurador síndico general. Por todo ello aducen que debe elegirse para tal cargo a un individuo del Cabildo de jurados para que, junto al regidor, forme parte de la mencionada Junta. Además, añaden que en 1769 se nombró a D. Juan Antonio Valera, jurado, junto al regidor D. Eusebio García Toledano, como comisionados municipales para la disposición del hospicio que se pretendió crear en esta ciudad por deseo expreso de S.M. ${ }^{40}$.

D. Eugenio Barrado, regidor, en el Ayuntamiento del día 25 de junio de 1773 propone una fórmula conciliatoria: que se eleve al rey la propuesta de que sea nombrado un caballero regidor, otro jurado y que también asista el síndico personero ${ }^{41}$.

El 14 de julio el Ayuntamiento decidió elevar el caso al Consejo de Castilla.

La disputa continuó y se fue agriando cada vez más, llegando a la discusión y discrepancia de quien representaba a toda la ciudad, al Común, si el Cabildo de jurados o el síndico personero, y de si era lícito o no usar de los caudales públicos para la defensa de las regalías de los señores diputados ${ }^{42}$.

Como puede observarse, la situación se iba enconando y con posibilidad de otras derivaciones que podrían poner en peligro el funcionamiento del Ayuntamiento y la paz de la ciudad. La calma renació al recibirse una Real Orden de fecha 4 de agosto por la que se mandaba que a todas las juntas que se celebrasen para la creación y conservación del hospicio, asistiesen el procurador síndico y personero del Común, para que representase en ellas al público, y un regidor del Ayuntamiento ${ }^{43}$.

Por fin se celebra la primera junta en el Palacio Arzobispal el 31 de enero de 1774. Se trató en ella del lugar de ubicación del hospicio. El cardenal propuso el Alcázar. El rey accedió a ello y proveyó lo necesario, tras diversas peticiones de Lorenzana, para su reconstrucción y adaptación a las nuevas necesidades.

Mientras, el prelado redactó las ordenanzas por las que debería regirse la casa hospicio y solicitó al rey que la acogiese, proponiendo se llamase

40 A.H.M.T., Informe presentado en el Ayuntamiento de 23 de junio. Libro de Actas del Ayuntamiento de Toledo de 1773, número 195.

41 Ibidem, Acta de la sesión de 25 de junio.

42 Ibidem, Acta de la sesión de 23 de julio.

43 Ibidem, Acta de la sesión de 9 de agosto. 
"Real Casa de Caridad". El monarca aceptó lo uno y lo otro y la tomó bajo su protección por Real Orden de 24 de diciembre de 1774.

Carlos III concedió al cardenal Lorenzana, además de los reales Alcázares, 13 bóvedas anejas al edificio, unas casas cocheras llamadas «de la Reina" (frente al Hospital de San Cruz), unos molinos en el Tajo, una pensión de 20.000 ducados anuales al Arzobispado de Toledo, para cuando vacase la Mitra ${ }^{44}$, así como otras concesiones ${ }^{45}$.

A través del Consejo de Castilla, el cardenal Lorenzana trató de obtener del Ayuntamiento de Toledo las dotaciones que en su día se proveyeron para el pretendido hospicio en 1769 (las dehesas de Renales y Villamucén y el arbitrio de 5.000 reales sobre el sobrante del aguardiente) y otros privilegios. Entre éstos destacan el que el hospicio pudiese coger libremente esparto para sus fábricas en una legua del contorno de la ciudad sin que nadie lo impidiese y el que las primeras materias para las citadas fábricas de la Casa de Caridad, así como las manufacturas y abastos del establecimiento quedasen exentos de pago a la entrada y salida por las puertas de la ciudad.

Un escrito de fecha 25 de junio de 1776, firmado por D. Antonio Martínez de Salazar, es recibido en el Ayuntamiento. En él se manifiestaba todo lo antedicho y se solicitaba un informe por parte de la ciudad ${ }^{46}$. El Ayuntamiento encarga dicho informe a $D$. Vicente Narváez, regidor, y $D$. Juan Pintado, jurado. Oído el mismo en la sesión de 10 de julio, se acuerda elevarle al Supremo Consejo de Castilla con arreglo a los siguientes términos: con respecto a los pastos de los despoblados, mantiene lo acordado en el Ayuntamiento de 13 de noviembre de 1769 y refrendado por el Consejo de Castilla con fecha 25 de octubre de 1770, mas, ya que los cede la ciudad sin interés alguno y de cuyo beneficio se iba a privar, deberán ser tomados por el vecino o vecinos de esta ciudad que los necesitase para su ganado a justa tasación de peritos nombrados por cada parte (hospicio y vecino) y un tercero en discordia por el corregidor de Toledo. En caso de no necesitar de los pastos de los despoblados los vecinos de esta ciudad, deberán ser preferidos para la misma tasación los de Fuensalida e igualmente a la inversa con el terreno separado para esta villa. Lo mismo deberá suceder si en algún tiempo se labrasen las

44 A.D.T., Legajo 3, n. ${ }^{\circ}$ 5. Carpeta Casa de Caridad.

45 Obtuvo maderas de las que en Aranjuez habia para las obras del Real Sitio. También le concedió el monarca las puertas y ventanas que se necesitaban para la capilla de la Casa de Caridad y que habian sido hechas para el Palacio de Madrid.

46 A.H.M.T., Libro de Actas del Ayuntamiento de Toledo de 1776, n..$^{\circ}$ 198. Carta-orden fechada en Madrid a 25 de junio de dicho año, vista en la sesión de 28 de junio. 
tierras. En el caso de no necesitarlos los vecinos de ambas ciudades, el hospicio podrá subastarlos libremente y percibir su importe.

Esta concesión debería entenderse por sólo el tiempo que exista el hospicio y continúe la manutención de pobres mendigos y necesitados; pues faltando esta condición habrá de volver a esta ciudad el usufructo de los mencionados despoblados y "consolidarse con la propiedad que a este efecto en sí reserva y por consiguiente sera tanvién sin perjuicio de la jurisdizión que a esta ciudad compete en todo el término de Renales y Villamuzen tanto lo separado o que se separe para esta ciudad y ospicio como para Fuensalida u otro pueblo comunero continuando en la posesión que hasta aquí ha tenido y tiene de nombrar Alcalde que regente la jurisdicción ordinaria en todo aquel territorio".

En lo referente a la asignación de los 500 ducados sobre la renta del aguardiente, se entiende que sólo dure por el tiempo que exista manutención de pobres mendigos y desvalidos en el hospicio y empezará a correr en cuentas de propios desde el primer día del año próximo de 1777 , si para entonces ya hubiere pobres de dicha clase en él o para el primero del año siguiente de aquel en que empezara a darse mantenimiento a pobres.

El Ayuntamiento deja bien claro que «por ninguna ni por otra cesión ni asignación ha de quedar obligada la ciudad a subrogar otras rentas ni dotación alguna aún cuando estas faltaran antes vien quedara del todo libre de contribuir con cosa alguna". También exige que como el hospicio se halla en Toledo y la ciudad subvenciona el citado instituto con sus caudales, deberán ser atendidos prioritariamente los pobres de ella, así como aquellos ministros y dependientes que se necesiten deberán ser vecinos o naturales de Toledo.

En cuanto a la petición de cortar esparto en exclusiva, se expone que los pastos del término de la Legua son abiertos y comunes a todos los vecinos de Toledo, excluyendo lo acotado para los ganados del abasto de carne; por consiguiente, el esparto es aprovechado por el ganado vacuno en la parte acotada y por los vecinos, especialmente los más necesitados, en la abierta. Se pone de manifiesto que por Real Cédula de 30 de marzo de 1549 está aprobada una ordenanza declarando pasto común a la Legua y da su aprovechamiento a los vecinos para cazar, coger turmas (criadillas de tierra), espárragos, setas, caracoles y escobas libremente; que con ello se evita entren los necesitados en las heredades privadas y en los cotos carniceriles. Además ya que el esparto no ha rendido nunca a beneficio de propios, no se conoce causa para impedir su aprovechamiento a los pobres que se emplean en su labor al amparo de las leyes que tratan del disfrute de pastos comunes. Por 10 mismo, el 
hospicio tendrá los mismos derechos que el resto de los vecinos, pero no en exclusiva, y podrá coger el esparto en el término de la Legua que se halle fuera de los cotos destinados a la manutención del ganado de abasto, como el resto de los demás pobres de Toledo.

Por último, y con respecto a poder introducir géneros por las puertas de la ciudad libremente, en to que se refiere a los derechos reales, el Ayuntamiento nada tiene que objetar, mas por lo que concierne a los arbitrios municipales.

«Se les tratará con la misma equidad que a los demás vecinos, pues se esperimenta graves perjuicios de conzeder particulares permisos a cuia sombra se cometen fácilmente repetidos fraudes aun sin poderlo remediar la comunidad que tiene el permiso por valerse de otros subalternos $y$ trajineros a quienes es quasi imposible el contener y resultaría grave perjuicio a los acreedores y censualistas contra los mismos arbitrios y municipales y no podría satisfacérseles ni de otros caudales publicos por los graves empeños que contra sí tienen" ${ }^{47}$.

Este informe, que debía enviarse al Real Consejo de Castilla para que aprobase lo acordado por el Ayuntamiento y diese vía libre a su ejecución, se llevó al Ayuntamiento de 11 de diciembre del mismo año, redactado adecuadamente por los comisarios encargados de ello y allí se dio el visto-bueno para su representación al citado organismo ${ }^{48}$.

Vemos cómo el Ayuntamiento intenta, ante todo, proteger sus derechos y los de los vecinos de la ciudad, sin perjuicio de atender a la vez a un fin tan loable como era la ayuda a los necesitados. Su política es de equilibrio; no puede conceder privilegios especiales a un instituto cuando por otra parte está elevando memoriales al rey en apoyo del Arte Mayor de la Seda, en contra de los privilegios que mantenían la Real Compañía de Comercio y Fábricas de Toledo y el fabricante particular y diputado del Ayuntamiento D. Vicente Díaz Benito en el tratamiento de los derechos de aduanas en la fabricación de géneros de seda. A la vez es ostensible la frialdad con que el Ayuntamiento acoge las peticiones del cardenal Lorenzana tras la desavenencia y desacuerdo generados en su seno a causa de la representación de este organismo en la Junta de la Casa de Caridad. Conflicto que ya hemos expuesto anteriormente.

No debió enviarse el informe pues, con fecha de 27 de enero de 1777 , el Real Consejo Supremo de Castilla dirigió una carta-orden al corregidor

47 Ibidem, Acta de la sesión de 10 de julio.

48 Ibidem, Acta de la sesión de 11 de diciembre. 
de la ciudad imperial reclamando su envío. El Ayuntamiento, con fecha 30 de enero, acordó se informase a la mayor brevedad por los caballeros comisarios encargados al efecto, con asistencia del síndico personero ${ }^{49}$.

El asunto es un poco confuso. Nada sabemos, pues nada nos dicen las actas del Ayuntamiento, acerca de los motivos de no elevarse a su destino el informe solicitado por el Consejo de Castilla, siendo que en la sesión de 10 de junio del año anterior, ya hemos visto, quedó elaborado y establecidas las cláusulas que la ciudad estimaba oportunas, y aprobada su redacción cinco meses más tarde. Un dato más que aumenta la confusión es que en el mismo Ayuntamiento de 30 de enero se nombra, en lugar del regidor $D$. Vicente Narváez, al también regidor $D$. Juan Fernández de Madrid, para confeccionar el informe, sin especificar el motivo del cese del susodicho regidor. ¿Por qué se cesa a D. Vicente Narváez? ¿Por qué tiene que elaborarse un nuevo informe si ya lo había sido con anterioridad y el Ayuntamiento había dado su aprobación al mismo y mandado se elevase al Real Consejo de Castilla? ¿Por qué ahora se incluye al síndico personero en la comisión? ¿Qué razones causan el retraso tan ostensible en la representación del informe?

Treinta y cinco días después de su nombramiento, D. Juan Antonio Fernández de Madrid solicita del Ayuntamiento se le excuse de realizar el informe, aduciendo tener muchas ocupaciones y solicita se nombre a otro caballero regidor para tal cometido. El Ayuntamiento, en su sesión de 7 de marzo, nombró a D. Luis Antonio Quero, regidor, y a D. Lucas Floresto, jurado, y al licenciado D. Manuel Buendía, con el encargo de que evacuaran a la mayor brevedad el informe, teniendo presente los antecedente que hubiera en este particular ${ }^{50}$.

La Junta de la Real Casa de Caridad, por medio de D. Nicolás Juan Paniagua y Toledo, regidor representante del Ayuntamiento en la misma, hace llegar al citado organismo una queja por el retraso en la evacuación de la dotación que la ciudad pensaba dedicar al hospicio y solicita su pronta resolución, pues la detención de los medios no permite disponer de su manejo y con ello se está perjudicando el desarrollo del fin propuesto ${ }^{51}$.

La dilación llega a sobrepasar los límites de lo tolerable, lo que obliga al Real Consejo Supremo de Castilla a enviar una carta-orden al corre-

49 A.H.M.T., Libro de Actas del Ayuntamiento de Toledo de 1777, n. ${ }^{\circ} 199$. Acta de la sesión de 30 de enero.

so lbidem, Acta de la sesión de 7 de marzo.

51 Ibidem, Acta de la sesión de 12 de mayo. 
gidor, su fecha de 16 de octubre, por la que se le comunica que al no haber evacuado a la fecha lo que se le solicitaba a pesar de la requisitoria enviada el 27 de enero pasado, se había acordado por decreto que si en el plazo de quince días no se había recibido el citado informe, el Consejo enviaría persona que, a costa del corregidor, pasara a ponerlo en práctica. El Ayuntamiento acordó que los señores agentes generales, con D. Francisco Mansilla, diputado, arreglasen el informe en el plazo exigido ${ }^{52}$.

En la sesión de 5 de noviembre, D. Simón Falzeto, regidor y agente general, dio cuenta a la ciudad que el procurador en corte le había notificado que ya había sido presentado en la oficina correspondiente el informe pedido por el Real Consejo sobre la agregación de los despoblados de Renales y Villamucén a la Real Casa de Caridad de Toledo.

Todos los indicios nos llevan a pensar que la dilación en la presentación del informe tenía tras si motivos no confesables abiertamente que suponemos pudieran ser de distinto signo y origen: institucionales, económicos, personales... Es curioso observar que en el primer proyecto de hospicio, el Ayuntamiento cooperó con rapidez y no puso ningún obstáculo o dificultad a su creación y desarrollo, siendo el Cabildo catedralicio el que lo hizo fracasar, y ahora que el cardenal Lorenzana habia superado, dentro de la institución eclesiástica, las dificultades o impedimentos con mayor o menor fortuna, es el Ayuntamiento el que parecía estorbar su logro o, como mínimo, no ayudaba a su fomento, progreso y adelanto, como en principio podía suponerse haría.

A pesar de todo, aún sin solucionar los problemas de rentas fijas para la manutención de la Casa de Caridad, el cardenal Lorenzana tomó la decisión de iniciar la vida de la misma. Se eligieron las personas que debían dirigirla y tras la primera misa en su capilla, celebrada por el propio cardenal el 13 de julio de 1776, se inauguró y abrió el instituto el 15 del mismo mes y año, estableciéndose en él fábricas de seda, lana, lino, cáñamo y esparto ${ }^{53}$.

Las obras para la reedificación y acondicionamiento del alcázar habían comenzado el 24 de febrero de 1774 y terminaron el 10 de agosto de 1776 y su coste ascendió a 2 quentos, 777.560 reales y 28 maravedís ${ }^{54}$.

La gran preocupación del cardenal Lorenzana era asegurar los medios económicos que hicieran posible el funcionamiento continuado de esta

52 Ibidem, Acta de la sesión de 22 de octubre.

53 A.D.P.T., Libro manuscrito: Rentas Fijas, n. ${ }^{\circ}$. Real Casa de Caridad.

${ }^{54}$ A.D.T. Legajo $1, n .{ }^{\circ} 7$. Carpeta Casa de Caridad. 
institución de beneficiencia, así como su duración en el tiempo. Por ello su obsesión era obtener rentas fijas abundantes, que no dejasen a la ventura y voluntad caritativa el mantenimiento del hospicio e incluir en el órgano directivo a representantes de los dos estamentos que, por su estabilidad y condición, tenían el deber de atender y atenuar las lacras sociales: Ayuntamiento y Cabildo catedralicio. Sin embargo, ni uno ni otro aceptaron con gran entusiasmo, y por diferentes razones, la creación del establecimiento. Como ya hemos visto, el Ayuntamiento demoró cuanto pudo la concesión de la dotación que la ciudad pensaba destinar al hospicio y negó una serie de privilegios que el cardenal solicitaba para el mismo. Por su parte, el cabildo opuso gran resistencia a la cesión de obras pías y limosnas de su patronato a la Casa de Caridad y llevó a efecto una labor de oposición larvada durante toda la existencia de aquella. Esta oposición se vio acrecedentada desde el momento que éste conoció la creación de una Junta para cuidar de la institución, lo que le privaba de ser el único protagonista. El obstrucionismo de los canónigos se manifiesta todavía en 1800,1803 y $1808^{55}$.

En este último año, el cabildo pretendió segregar de la Casa de Caridad los granos de la limosna "Pan del Claustro" para aplicar las 600 fanegas de trigo al Hospital de Santa Cruz, de niños expósitos, al haber vendido sus fincas. El director de la Casa de Caridad, don Josef Hortega Álvarez, se opuso a tal pretensión aduciendo que al subsodicho hospital le quedaban los capitales y las rentas, mientras la Casa de Caridad no tenía sobrantes, sino gran necesidad y además el cabildo podía echar mano de otros arbitrios que poseía para ayudar al Hospital de Expósitos sin desposeer a la Casa de Caridad de unos medios que precisaba. Entre los posibles recursos del Cabildo se hallaban los productos de las aMemorias de Ventanas" y las de "Peña de Toledo", a más de

«el considerable fondo de los que se dicen Capuces de las memorias de Mármol, Velasco, León, Garay, Agraz, Ortiz, Sotomayor, Urraca, Alcibar, Arcayos, y Martín Messino, destinadas para limosna en Toledo se hallan sin uso, pues habiendo el Excmo. Señor Cardenal de Lorenzana, pensando agregarlas a esta Real Casa, halló resistencia por entonces en el cabildo, por parecerle a éste que en la agregación se variava substancialmente el destino, y esta resistencia dio por entonces motivo a que el Rey Don Carlos tercero (de gloriosa memoria) mandase suspender la inbersión de sus caudales o productos: Ello es que anualmente se repartian entre pobres; pero también es cierto que hace muchos años que a pretexto de dicha Real Orden nada se reparte..." ${ }^{56}$.

55 Fuentes lázaro, J., Historia de la Real Casa de Caridad..., op. cit., págs. 82-84.

56 A.D.T. Carta del Director de la Casa de Caridad, al comienzo de un cuadernillo que contiene un informe del mismo sobre el hospicio. Carpeta Casa de Caridad. 
Por el contrario, la disposición del rey Carlos III fue extraordinaria, protegiendo al instituto con donaciones, privilegios y continuas ayudas materiales y morales, como el que la fundación pudiera llevar el título de "Real», y la entrega del cardenal fue total. Gran Parte de los fondos de los que podía disponer la Casa de Caridad provenían del patrimonio del propio Lorenzana, el cual cede a esta institución algunas de sus propiedades, que le pertenecian bien por heredad o por compra, y costea la construcción de edificaciones que posteriormente dona al hospicio.

Lorenzana, no sólo se preocupó de la parte material de su obra benéfica en Toledo, dotándola con magnanimidad y largueza, mientras permaneció en la diócesis, sino que mantuvo este mismo interés aun lejos de ella, como cuando en 1797 hubo de salir de España a Roma, lugar del que no volvería a su país por hallarse en un destierro no confirmado oficialmente. Dos años antes de su muerte, el 12 de agosto de 1802, otorgaba testamento. Entre sus cláusulas realzamos la siguiente:

"De todo lo demás que después de satisfechos dichos gastos y Legados arriba expresados, quedare existente en España de mis rentas, o en efectivo o en deudas a mi favor, o que por cualquier título me pertenezca, teniendo presente la naturaleza de dichos bienes, que son Eclesiásticos, y proviene de Diezmos del Arzobispado de Toledo, nombro e instituyo Herederos Universales al Hospicio o Casa de Caridad de la Ciudad de Toledo y al Hospicio de la Ciudad de Ciudad-Real que ambos han sido fundados y establecidos por mí; y es mi voluntad que haciendo de dicho remanente tres partes iguales, las dos se apliquen al Hospicio de Toledo, y la otra tercera parte al Hospicio de Ciudad-Real, siendo mi mayor deseo que dichos Hospicios prosperen y vayan siempre en aumento por el gran bien que resultará de esto al Arzobispado, y aún a todo el Reyno" ${ }^{57}$.

El total de las rentas líquidas a repartir entre las dos Casas de Caridad, después de efectuar lo ordenado por el cardenal en su testamento, ascendió a 2.030 .974 reales y 6 maravedís, distribuidas en metálico, vales reales y créditos ${ }^{58}$.

\section{OBJETIVOS DE SU CREACIÓN Y FUNCIONAMIENTO INTERNO}

La Real Casa de Caridad de Toledo nació con unas motivaciones y unos objetivos muy específicos, determinados y concretos: recoger a los

\footnotetext{
pág. 24.

s8 A.D.T.P., Leg. Casa de Caridad, n. ${ }^{\circ} 31$.
}

57 Gutiérfez Garcia-Brazales, M., Francisco Antonio de Lorenzana, el Cardenal..., op. cit., 
pobres mendigos de ambos sexos, huérfanos y desvalidos, procurando su felicidad espiritual y corporal liberándolos de la mendicidad y haciéndoles útiles al Estado y a sí mismos mediante una enseñanza e instrucción precisa, inspirada en el temor de Dios y pureza de costumbres, y una ocupación honesta, productiva y provechosa, proporcionada a sus fuerzas, aplicándolos a la manufactura en las fábricas de lana, seda, cáñamo y lino que se habrían de instalar en ella, de acuerdo con la habilidad, ingenio y posibilidades de cada uno. Esto es lo que queda establecido en los artículos $2 .^{\circ}$ y $3^{\circ}$ del Título I de sus Ordenanzas ${ }^{59}$. En el primero se nombra patrona a Ntra. Sra. María de la Caridad, acogiéndose a su protección y para que por su mediación se ablandasen los corazones de los cristianos en bien de los necesitados y de la utilidad pública. El resto de los artículos del mencionado Título I se refieren todos a la disciplina de los pobres del establecimiento: vestido, comida, horarios de trabajo y descanso, sobre enfermos y entierros, asi como sobre el precepto de confesión y comunión.

El Título Il específica, por medio de nueve artículos, el órgano de gobierno, su composición, obligaciones, lugar de reunión, conocimiento de cuentas y destino de los caudales sobrantes. El citado órgano sería una Junta de Dirección, compuesta por el presidente —el arzobispo de Toledo-, dos diputados del Ilmo. Cabildo, el regidor decano del Ayuntamiento, el procurador jurado, el procurador del Común o personero y el director de la Casa, que según se específica en el Título IV, artículo 26, siempre lo sería un canónigo o dignidad de la Iglesia Primada.

El Título III, en su único artículo, establece que la jurisdicción de justicia para todo lo concerniente a la Casa de Caridad quedará en el corregidor de Toledo, en calidad de juez protector de los pobres y en nombre de S.M.

El Título IV, como ya hemos indicado anteriormente, trata de la dirección del centro. En él se especifican los derechos y deberes del cargo. Éste siempre debería recaer en un canónigo o dignidad de la Iglesia Primada, que sería elegido cada tres años, con posibilidad de reelección tantas veces como se creyera preciso y oportuno. Tendría habitación en la Real Casa de Caridad y su dotación sería de 300 ducados anuales a más de ración doble de carne, pan y utensilios para sus criados.

s9 A.H.M.T. «Ordenanzas para la Real Casa de Caridad de Toledo, aprobadas por su Magestad", Madrid MDCCLXXV. Por D. Joachin IBARRA, Impresor de Cámara de S.M., Colección Borbón-Lorenzana. Bibl. Públ., de Toledo. También se hallan en el Ayuntamiento de Toledo. 
Los demás títulos, hasta culminar los trece de que se componen las ordenanzas, fijan las obligaciones y dotaciones de los empleados, las cuales quedaron estipuladas en:

Tesorero: 800 ducados anuales, habitación y ración doble para un criado. Mayordomo: 500 ducados, habitación y ración doble para un criado. Capellán: 300 ducados, habitación, ración doble y utensilios. Celador: 300 ducados, habitación y ración. Celadora: 100 ducados, habitación y ración. Agente solicitador: 200 ducados, ración doble y habitación. Escribano: 50 ducados anuales. Mayoral: Debería ser nombrado de entre los pobres. Su dotación sería de un real además de la ración ordinaria, como el resto de los asilados. Mayorala: Nombrada como el mayoral. No se específica la dotación, aunque debería ser similar a la del cargo masculino. Maestros y maestras de fábricas: Salario a juicio de la Junta. Sobrestantes: Estarían directamente bajo el mando de los maestros y maestras de fábrica.

Los artículos 84 y 85 , pertecientes al Título XIII, establecen de forma taxativa la separación de sexos en todos los ámbitos de la Casa: trabajo, ocio, misa, comedor, etc.

Estas Ordenanzas, formadas por el cardenal Lorenzana y aprobadas por el rey con fecha 24 de diciembre de 1774, conforman una estructura capaz de constituir en organismo autónomo a la Real Casa de Caridad, lo que unido a la pretensión de que dispusiese de unas rentas fijas, seguras y suficientes, le daban la posibilidad de vivir en sí y por sí misma, sin que ello impidiera una intensa relación con la ciudad en que se hallaba ubicada, a través de los oficiales y maestros que, no perteneciendo al instituto, acudían diariamente al trabajo en sus telares, de los pobres que salían a servir a casas de vecinos y del comercio de los productos manufacturados en sus propios talleres.

Tal vez, este establecimiento fue, durante los primeros años de su existencia, uno de los más provechosos del reino. Se contaban más de 700 pobres recogidos y aplicados a las manufacturas de sus fábricas, en las que se realizaban labores de esparto, lino, lana, torcidos de seda, ornamentos de iglesia, toda clase de listonería, medias y ropas de seda anchas y estrechas, con labores y sin ellas. Llegó a haber una media de 124 telares y se mantuvieron 150 operarios de fuera ${ }^{60}$.

so A.H.M.T. Este número de pobres se indica en un escrito de la Contaduria de la Casa de Caridad, que en 15 de junio de 1820 realiza un informe de su estado, por orden del Director de la misma. Leg. 11. Beneficencia (1601-1892). Sin embargo, en el legajo Casa de Caridad del A.H.M.T., hay otro escrito de J. Manuel Parro de 17 de septiembre de 1837, dirigido a la Junta de Beneficencia de Toledo, en el que dice llegó a haber más de 850. 
El establecimiento contaba también con una escuela de primeras letras, donde los niños aprendian a leer, escribir, contar y doctrina cristiana. Cuando se hallaban perfectamente instruidos pasaban a las fábricas a aprender un oficio, donde debían permanecer un mínimo de cinco años con el fin de rentabilizar el coste que su enseñanza ocasionaba, al cabo de los cuales, hallándose capaces para trabajar, se les concedía el título de oficiales y podian salir de la Casa a emplearse, si así lo deseaban, en esta capital o fuera de ella.

De este sistema resultaba un bien general por el crecido número de pobres que se favorecieron, hallándose de entre ellos muchos que descubrieron un ingenio extraordinario para las referidas manufacturas, por lo que algunos quedaron de maestros-directores de las citadas fábricas, otros las pusieron particulares en sus casas y alguno se empleó en dirigir una de las establecidas por el rey. Muchos años después se conocían oficiales de las expresadas artes que habían debido su educación y enseñanza a esta casa de beneficencia.

Para aumentar la instrucción de los asilados en la perfección y buen gusto en las labores, se creo una escuela de Nobles Artes con maestros de pintura, escultura y arquitectura, a la que concurrian por la noche, después de la asistencia a sus obradores, siendo al tiempo abierta a los vecinos de la ciudad que desearan asistir. En ella se repartían premios mensualmente con el fin de estimular a los alumnos en su adelantamiento ${ }^{61}$.

En todo y por todo, a pesar de los defectos que se le puedan achacar y de las filias y fobias que pudiese provocar, la Real Casa de Caridad creada y levantada por el cardenal Lorenzana en Toledo, es ejemplo y modelo de las instituciones benéficas ilustradas, en total acuerdo con la mentalidad del siglo XVIII, si nos atenemos a las manifestaciones de los más conspicuos representantes españoles del siglo de las luces.

\section{LAS FÁBRICAS TEXTILES DE LA CASA DE CARIDAD}

Las nuevas ideas ilustradas sobre la beneficencia cambiaron totalmente el sistema asistencial en el siglo xvill. Ahora se trataba de unir el pragmatismo con la caridad, sosteniendo y amparando a los auténticamente impedidos y necesitados, recogiéndolos en hospicios donde se les daba

\footnotetext{
61 A.H.M.T. Informe de la Contaduría de la Casa de Caridad de 15 de junio de 1820. Leg. 11 de Beneficencia (1601-1892).
} 
atención física y religiosa, a la vez que se instruía y educaba a los niños en ellos recluidos y se proporcionaba trabajo digno y adecuado a sus posibilidades a los hombres y mujeres en ellos refugiados, en las manufacturas instaladas en los mencionados institutos. Con este sistema se obtenían diversos logros:

a) Atender las necesidades de los marginados, cuidando a los auténticamente impedidos y menesterosos.

b) Limpiar las calles y plazas de las ciudades españolas de indigentes pedigüeños, que tanto molestaban y tan mala imagen proporcionaban.

c) Reinsertar en la sociedad a aquellos que se hallaban capacitados para aprender un oficio, proporcionándoles un medio de subsistencia en el futuro.

d) Dignificar la vida de los pobres facilitándoles la satisfacción de sentirse útiles a sí mismos y a la sociedad con un trabajo digno y adecuado a sus posibilidades y capacidades.

e) Evitar posibles focos delictivos y subversivos que podían ser astutamente manejados por aquellos que desearan perturbar el orden social existente.

f) Regenerar la economía nacional, reduciendo al trabajo y productividad a mucha gente, acabando así con uno de los mayores lastres, a fin de conseguir el bienestar del conjunto de la sociedad.

g) Desposeer a la Iglesia de una de sus bases de adhesión popular, a la vez que maniatar parte de sus caudales a fin de que no pudiesen ser utilizados contra el regalismo monárquico.

h) Procurar un cambio de mentalidad para arraigar en la cultura española la idea de la dignidad y honorabilidad del trabajo industrial y comercial.

i) Hacer desaparecer el conformismo fatalista en los necesitados y su liberal e incontrolada manera de vivir.

Esa conjunción de caridad espiritual y pragmatismo material es lo que lleva a la instalación de cuatro fábricas textiles en la Casa de Caridad. Para unos su puesta en marcha sólo produjo beneficios, viendo en ellas el punto de inflexión en la decadencia de Toledo. Así Antonio Ponz escribe con exagerado optimismo:

"salen por consiguiente de dicha benéfica oficina, instruidos ya por su respectivos Maestros, muchos oficiales diestros, y de buenas costumbres que, extendiéndose por el pueblo, van ocupando los telares que estaban sin uso desde la deplorable decadencia de las fábricas, acreditando así 
la experiencia que este último establecimiento es capaz de hacer opulenta la Ciudad, y de restituir dichas fábricas a su explendor antiguo" ${ }^{62}$.

Por el contrario, para Larruga y Boneta ${ }^{63}$, quizás influenciado por las quejas de los veedores y maestros del Arte de la lana y la seda toledanos, las fábricas instaladas en el Alcázar sólo servirían para hacer una desleal competencia a los laneros y sederos de la ciudad, debido a la política del director de la Casa de Caridad de fabricar las mismas manufacturas y géneros que los fabricantes particulares y aprovecharse de poderlos vender a precios inferiores, dado los privilegios y posibilidades con que contaba la institución.

Los maestros laneros elevaron un escrito con fecha de 5 de septiembre de $1777^{64}$ en el que se quejaban de que no había comercio para tanta producción ni suficientes operarios en la ciudad, especialmente oficiales e hilanderas, pues además de los tejedores particulares se habían establecido fábricas de lana en el Hospital de Santa Cruz y posteriormente en la Casa de Caridad. Asimismo, se lamentaban de que, tanto los unos como las otras prefiriesen trabajar en ambas instituciones porque allí recibían un estipendio mayor que el que normal o regularmente se pagaba en la ciudad y porque en estos establecimientos se disimulaban los defectos que no pasarian en las fábricas particulares. Por último, se dolían de que las compras masivas de lana realizadas por ambas instituciones habían alterado excesivamente los precios de la misma. Todo ello, exponen, traía como consecuencia su ruina, el cierre de fábricas y el cese de casi todos los telares, quedando, por tanto, la mayoría expuestos a mendigar y obligados a formar parte de la institución que ahora los empobrecía. Solicitaban que sólo se diese trabajo en los dos establecimientos a aquellos que lo necesitasen por hallarse sin él y en la mendicidad, y se realizasen sólo «aquellas actividades de que carezca el común del pueblo", cuya puesta en marcha pueda redundar en mayores beneficios para todos, o sólo se labrasen labores que cubrieran las necesidades de los pobres y no saliesen al mercado.

También los veedores del Arte Mayor de la Seda manifestaron su rechazo a la fábrica de la Casa de Caridad por los perjuicios que la misma

62 Ponz, Antonio, Viaje de España, tomo I, 3. a edición corregida y aumentada. Madrid 1787, pág. 125.

63 LaRRuga y Boneta, E., Memorias políticas y económicas sobre los frutos, comercio, fábricas y Minas de España, con inclusión de los reales decretos, órdenes, cédulas, aranceles y ordenanzas expedidas para su gobierno y fomento, 45 vols. Madrid 1787-1800, vol. VIII, pág. 48.

64 A.D.P.T., Leg. n. ${ }^{\circ}$, Casa de Caridad. 
ocasionaba a los sederos toledanos. Esta oposición venía dada por los privilegios que aquella había obtenido en el año $1777^{65}$ :

1. Los veedores del Arte Mayor de la Seda de Toledo no tendrían competencia para visitar la fábrica y reconocer los tejidos que se fabricasen en ella, así como tampoco en el alistamiento de operarios, pues S.M. deseaba que se manejasen igual que las que corrían de su cuenta.

2. La Junta de la Casa de Caridad podía nombrar veedor propio y sellar sus tejidos con sello propio.

3. - Los jóvenes aprendices de la Casa de Caridad que llevasen el tiempo necesario, obtendrían certificación del veedor o maestrodirector de sus fábricas y podrían ser admitidos a examen por el Arte Mayor y hallándolos hábiles obtendrían sus títulos de maestros.

Además se concedió franquicia de derechos reales en los géneros fabricados en ella ${ }^{66}$.

De las cuatro fábricas instaladas en la Real Casa de Caridad de Toledo, la de menor entidad fue la de esparto. En ella se fabricaban pleitas recias, entrerrecias, corridas y menudas, tomizas redondas, rollos de treinta varas, rollos corridos, rollos chicos, atillos, sogas y lías. La mayor parte de la producción se destinaba a cubrir las necesidades del establecimiento. En el primer año de funcionamiento, es decir, hasta el 31 de agosto de 1777 , trabajaron en el esparto 23 pobres ( 16 hombres y niños y 7 mujeres y niñas). Sin embargo, en la elaboración de estos productos se empleaba preferente y esencialmente a los ancianos, por ser un trabajo tranquilo y que no necesitaba un gran esfuerzo, sino paciencia y habilidad. El trabajo no se realizaba exclusivamente dentro de la Casa de Caridad, donde se dedicaban a este menester 42 pobres ancianos en 1791 y 1792, decayendo a 17 en 1793, sino también se daba trabajo a los ancianos de los pueblos contiguos a la ciudad, estando entretenidos en este ejercicio 62 en los dos citados primeros años y 32 en el tercero.

Poseemos los datos completos de producción y precios de los productos de cuatro años: $1790-93{ }^{67}$. Los dos primeros años la producción se mantuvo en niveles semejantes, decayendo en 1792 y llegando a ser la mitad en 1793. Sin embargo, en cuanto al valor de lo generado, y teniendo en cuenta que los precios de los productos no variaron prácti-

65 Ibidem.

66 A.D.T., Leg. 2, n. ${ }^{\circ}$, Carpeta Casa de Caridad. Fondo Lorenzana.

67 A.H.M.T., Leg. Casa de Caridad. 
camente a lo largo de los cuatro años de los que poseemos noticias, fue precisamente el de 1793 el que alcanzó una mayor cuantía con 21.000 reales en números redondos, mientras que el que rindió menos numerario fue el de 1790, que sólo llegó a 11.500 reales. Este aumento de casi un 100 por 100 en el valor de lo manufacturado en el último año de los reseñados, se debe a un casi abandono de la fabricación de los géneros rentables y un aumento, por el contrario, de aquellos productos, como rollos y pleitas, que alcanzaban un mayor valor en el mercado.

Otra de las fábricas de menor importancia fue la de lino. Daba trabajo en 1777 a doce pobres. En 1788 había 60 operarios, reduciéndose a 30 en 1790. Veintiséis pobres, más siete oficiales vecinos de Toledo trabajaban en ella a fines de 1792. Este número bajó a 17 pobres de la Casa $y$ tres oficiales de fuera de ella en 1793.

Los telares corrientes ascendian a 24 en 1788, llegando a 30 en 1790 y 1792.

Podemos dar noticias por documentos hallados en el A.H.M.T. de los productos fabricados y de sus respectivos precios desde 1786 a $1793^{68}$. Se fabricaban lienzos, cotíes, cintas, belduques, estopas, mantelerías e hiladillo. Los precios, al igual que los de los productos de esparto, se mantuvieron estables. La producción, por regla general, retrocede a medida que avanzan los años. Esto, unido a la disminución de trabajadores empleados, nos señala la decadencia, o por lo menos el escaso futuro de la fábrica de lino.

Los productos elaborados por esta fábrica eran de mayor valor que los de la de esparto; sin embargo, como el coste de producción era superior, el rendimiento no era óptimo ni atractivo.

El valor de la producción en estos años fue el siguiente:

$$
\begin{array}{ll}
\text { Año } 1788=70.185 \mathrm{rs} . & \text { Año } 1791=34.350 \mathrm{rs} . \\
\text { Año } 1789=49.000 \mathrm{rs} . & \text { Año } 1792=23.850 \mathrm{rs} . \\
\text { Año } 1790=40.600 \mathrm{rs} . & \text { Año } 1793=32.750 \mathrm{rs} .
\end{array}
$$

Puede observarse claramente la pérdida continua de rentabilidad a

\footnotetext{
68 Los datos de 1789 se han obtenido de una declaración de géneros y especies de la ciudad. Los de 1790, 1791, 1792 y 1793, de los extractos individuales de géneros fabricados de seda, lana, lino y esparto. Todos ellos en el Leg. Casa de Caridad, A.H.M.T. Los de 1789, sólo corresponden a dos documentos sueltos sobre gastos de la Fábrica de lino en 31 de enero y 31 de agosto, A.D.P.T. Por lo tanto, los datos que damos para el año 1789 los hemos extrapolado de sólo dos meses, de los que haciendo una media, hemos calculado to fabricado por más y lo hemos multiplicado por 12 para obtener lo que, teóricamente, se elaboraría en el año completo. Es por lo que los datos de ese año no son todo lo exactos que deseariamos.
} 
medida que avanzan los años. Sólo en el último de los reseñados se da un aumento del rendimiento, pero que no alcanza siquiera el de dos años antes.

Los géneros producidos por esta fábrica se vendían en la ciudad, excepto el lienzo, del que se empleaba toda la producción en el vestuario de los pobres de la Casa.

La fábrica de lana, junto a la de seda, fue la más importante de las instaladas en la Casa de Caridad, y la que tuvo un futuro más largo, pues se mantendrá hasta la agregación de la institución al asilo de pobres de San Sebastián en 1838.

Al contrario de las dos fábricas de las cuales ya hemos hablado anteriormente, paradógicamente fue aumentando el número de empleados mientras disminuía su producción. A los cinco meses de la apertura del hospicio, es decir, en diciembre de 1776, había destinados en esta fábrica 45 pobres (34 hombres y 11 mujeres) ${ }^{69}$. En 1789 había empleados 34 oficiales. A fines de 1792 se hallaban aplicados en ella 67 pobres de ambos sexos, 37 oficiales de fuera entre tejedores, cardadores y peinadoras, y 357 hilanderas en varios pueblos de los alrededores de Toledo y distantes de la ciudad más de 4 ó 5 leguas. En 1793 estuvieron empleados en esta fábrica 92 pobres filiados en la Casa de Caridad, 83 oficiales tejedores y peinadores y 294 hilanderas.

En 1790 la fábrica de lana contaba con 28 telares. En 1793 tenía 24 de estameñas finas, 4 de gerguillas y 9 para paños y bayetones que se habían mandado construir para elaborar el vestuario para la tropa.

Al igual que los géneros de las fábricas de lino y esparto, los de lana se mantuvieron constantes en el precio a lo largo de los cuatro años de los que poseemos datos precisos y exactos (1790-93) ${ }^{70}$. Los géneros que se fabricaban eran: paños catorceanos, estameñas finas y ordinarias, bayetones, bayetas, sayales, jerguillas y paños dieciochenos.

De los cuatro años indicados, el de mayor producción fue el de 1791 con 28.574 varas y con un valor en el mercado de 343.794 reales, obteniendo tanto en fabricación de géneros como en valor de los mismos más del 100 por 100 del año anterior. En un nivel semejante se mantuvo

A.D.T. Leg. 2, n. 8 , Carpeta Casa de Caridad, Fondo Lorenzana.

70 A.H.M.T., Leg. Casa de Caridad. Los datos tomados de 1790 a 1793 son extractos individuales de los géneros fabricados de seda, lana, lino y esparto. Los correspondientes a 1789 han sido extrapolados de 4 documentos que dan cuenta de los gastos de la fábrica de lana en cuatro meses distintos, A.D.P.T. Es por lo que los datos referentes a este año sólo son relativos. 
1792, aunque con tendencia a la baja. Decayó mucho la fábrica en 1793 , año en el que se dejaron de fabricar estameñas ordinarias, bayetones, bayetas y sayales, aunque aparecen por primera vez los paños dieciochenos. 1790 fue un año flojo en producción, aunque mejor que 1793.

Entre las diversas actividades que necesitaba la elaboración de tejidos de lana, la del batanado es una de las más importantes y costosas, por eso, el cardenal Lorenzana mandó construir un batán en el arroyo de la Rosa, bajo la ermita de Ntra. Sra. de la Guía; no obstante todavia en 1789 la fábrica de lana de la Casa de Caridad enviaba a batanar sus tejidos, o parte de ellos, al batán de don Eugenio de Otaola, vecino de Toledo. Este mismo industrial tintaba también los géneros que aquélla le enviaba.

La importancia de la fábrica de lana de la Casa de Caridad la podemos comprobar comparándola con la situación de la de la ciudad: En 1790 había en Toledo 67 telares, donde trabajaban 265 operarios, además de 412 hilanderas, que produjeron 68.002 varas de distintos géneros por un importe bruto de 703.958 reales. En 1792 la producción fue de 66.760 varas de tejidos, que generaron un valor total de 706.247 reales. Este rendimiento se realizó con 66 telares, 201 operarios y 400 hilanderas ${ }^{71}$. Mientras tanto, la Casa de Caridad poseía en el primero de los años indicados 28 telares, 10 que supone un 41,7 por 100 del total y sin embargo, produjo el 19,5 por 100 de las varas de géneros de lana elaborados en Toledo. Es decir, los tejedores particulares, con el 58,3 por 100 de los telares, produjeron el 80,5 por 100 de los tejidos, con un valor bruto del 76,6 por 100.

El año 1792 podemos considerarlo normal en la producción del hospicio, pues con el 39,8 por 100 de operarios de los telares de la ciudad, se produjo un 35 por 100 de lo que se elaboró en ella y por un valor del 40,4 por 100 .

En 1793, por un informe elevado por los veedores León García de Burgos y Benito Barbero, vecinos de Toledo y maestros y veedores del gremio y fábricas de lana de esta ciudad, conocemos que en ella trabajaban 16 maestros, 68 oficiales y 358 hilanderas. Había 13 telares anchos en uso y 7,5 angostos. Con ellos fabricaron en todo el año (excluida la Casa de Caridad) 687 piezas con 39.732 varas en total ${ }^{72}$. Hacemos

7 Documentos con los datos de la ciudad sobre Frutos comestibles y materias primeras de las Artes, Años 1788, 1790 y 1792 . (No se dan datos del primer año por hallarse muy deteriorado el documento y no poderse lograr noticias completas.) A.H.M.T., Leg. Casa de Caridad.

72 A.H.M.T. Cuadernillo con razón de la situación de la fábrica de lana en 1793. Informe de los veedores, Leg. Casa de Caridad. 
notar que, con casi el doble número de telares, la fábrica de la Casa de Caridad produjo sólo el 28,38 por 100 de varas de tejidos que los tejedores particulares, lo que supone un 22,1 por 100 del total de los elaborados en la ciudad, y con un mayor número de personas trabajando, aunque los técnicos fuesen similares si sumamos los maestros y oficiales produciendo en la ciudad.

En cuanto al rendimiento, los fabricantes particulares produjeron por un valor de 405.720 reales, mientras la Casa de Caridad lo hizo por valor de 144.922 reales, lo que supone el 35,71 por 100 de aquellos y el 26,3 por 100 del total generado por las fábricas de lana de Toledo.

Todo lo expuesto nos demuestra que el rendimiento de la fábrica del hospicio era menor que el de los particulares, así como también lo era la producción y el valor de lo elaborado, con mayor número de empleados $y$ telares.

La fábrica de seda era la mayor y más productiva de todas las instaladas en la Casa de Caridad. Al finalizar el primer año de su existencia se había fabricado dos pares de medias, 4.585 pañuelos y 33.955 varas de diferentes tejidos: tercianelas, tafetanes, espumillón, bandas, terciopelo, punto real, galones, cintas de aguas, ceñidores, colonias, terciados y fittas, de los que se vendieron el 85 por $100^{73}$.

La producción y su valor bruto entre 1790 y 1793 fue el siguiente:

\begin{tabular}{cccc}
\hline Año & Varas & Unidades * & Valor \\
\hline 1970 & $5.979,5$ & 19.866 & $755.186,50$ rs. \\
1791 & $5.886,5$ & 21.466 & $795.615,40$ rs. \\
1792 & $6.449,5$ & 20.962 & $779.117,75$ rs. \\
1793 & $5.123,0$ & 19.469 & $707.867,25$ rs. \\
\hline
\end{tabular}

* Las unidades se refieren a productos acabados: pañuelos, bandas, medias y gorros.

Podemos observar que no hubo grandes oscilaciones de producción así como tampoco en el valor de lo elaborado, solamente en 1793 se produjo una caída en el valor de lo manufacturado, suponiendo un 11,5

73 A.D.T. Documento suelto con datos sobre el estado de la Casa de Caridad del 6 de septiembre de 1777. Leg. $2, n .{ }^{\circ} 8$, Carpeta Casa de Caridad, Fondo Lorenzana. 
por 100 menos que el año anterior y un 9,6 por 100 menos que la media de los tres años anteriores.

Fue la más estable de todas las fábricas, aunque hubiese oscilaciones notables en la fabricación de diversos géneros, que es posible se debiese a las necesidades del mercado.

En esta fábrica, según Larruga y Boneta ${ }^{74}$, existían 44 telares en 1786. Por documentos hallados en el A.H.M.T., sabemos que en 1790 habian alcanzado el número de 56, reduciéndose a 42 en 1793. Los empleados que en ella trabajaban ascendían a 132 pobres de ambos sexos, filiados en la Casa y 77 jornaleros vecinos de la ciudad, en 1792. En el año siguiente eran 124 los pobres aplicados en la elaboración de tejidos de seda y 68 los jornaleros vecinos de la ciudad ${ }^{75}$.

En este último año, además de la fábrica de tejidos de seda corrientes, se instaló en la Casa de Caridad otra de ornamenos de iglesia con cinco telares, en los que se empleaban seis pobres de la Casa y siete operarios de fuera de ella. Se realizaron en la misma siete capas de cioro, $23 \mathrm{ca}$ sullas con todos sus recados, ocho dalmáticas, igualmente con todos sus aditamentos, tres paños de facistol, dos paños de hombros y seis varas de espolín de seda. El valor de las piezas era ajustado antes, según las clases de oros y platas que llevara cada una ${ }^{76}$. Esta fábrica de telas de oro nos informa don Antonio Ponz ${ }^{77}$, se puso en Toledo, en la Casa de Caridad, porque siendo arzobispo de Méjico D. Alfonso Núñez, y conociendo que el cabildo de aquella ciudad trataba de hacer un gasto considerable en ricas telas de oro, de fuera del reino, indujo a que la fabricación se hiciera en Toledo y hubo que empezar por hacer a propósito los telares y otros instrumentos para tejerlas.

La decadencia de las manufacturas sederas en Toledo iba en aumento al no poder competir con las fábricas valencianas ni con los tejidos importados del extranjero, ruina que en 1774 era muy notable, lo que producía un aumento significativo de parados, engrosando el número de pobres los obreros y obreras que vivían del arte de la seda. A esta situación vino a sumarse la creación de la fábrica de seda de la Casa de Caridad, aunque, como ya vimos, su impacto es visto desde dos ópticas totalmente contradictorias. La una acusa a aquella de terminar de arruinar la escasa

74 Larfuga y Boneta, E., op. cit., tomo VIII, pág. 46.

75 Extracto individual de los géneros fabricados de seda, lana, lino y esparto y en la nueva fábrica de ornamentos de Iglesia en el año de 1793. A.H.M.T. Leg. Casa de Caridad.

76 Ibidem.

77 Ponz, A., op. cit., pág. 232. 
industria sedera particular existente en la ciudad y la otra expone, por el contrario, que «la total decadencia que de muchos años a esta parte experimentaba Toledo en sus antiguas y famosas fábricas de seda casi momentáneamente ha desaparecido, y se ven hoy en estado floreciente en el Alcázar y aún fuera de él» ${ }^{78}$.

Si en un principio la fábrica de seda de la Casa de Caridad llegó a tener una media de 124 telares, en los que trabajaban, además de un alto número de pobres recogidos en el hospicio, 150 operarios de fuera de él, las últimas dos décadas del siglo XVIII fueron de total decadencia, acorde con la situación del resto de la ciudad. No obstante, este establecimiento, con una media de 50 telares por año, mantenía el 30 por 100 de los corrientes existentes en Toledo, cantidad que se acomoda adecuadamente con la producción y, sobre todo, con el valor bruto de lo elaborado. Esto nos demuestra que al ser la producción de tejidos de seda de gran arraigo y tradición en Toledo, los oficiales que trabajaban en la fábrica de la Casa de Caridad tenían la cualificación adecuada y su rendimiento era el correcto y normal en este tipo de tejidos.

Por una serie de razones que no son del caso en este breve trabajo, la Casa de Caridad inició su declive a partir del ostracismo a que fue sometido su fundador en 1797 . Su ruina se vio incrementada y completada con la actuación de las tropas napoleónicas que durante la ocupación de Toledo se alojaron en el Alcázar, donde se hallaba ubicada la Casa de Caridad. Después de saquearla y cometer en ella grandes destrozos, actos por otra parte habituales en los invasores franceses, que quizás, como consigna general habían recibido la orden de desmantelar y destruir la industria española, prendieron fuego al edificio ${ }^{79}$ en 1810 destruyendo todos los telares de seda y la mayoría de los de lana, así como utensilios y maquinaria de las fábricas; también quedaron destruidos los efectos de la Academia de las tres nobles artes y el batán llamado de la Rosa, propiedad de la Casa de Caridad, donde se batanaban las ropas de la fábrica de lana. Sólo pudieron salvarse algunos géneros de seda cuyo valor sirvió en los siguientes años para mantener a los pobres con la mayor estrechez, pues las rentas se fueron perdiendo con el paso de los años, quedando enormemente reducidas y no poder obtener ingresos de sus manufacturas pues el establecimiento perdió todo lo necesario para fabricar tejidos de seda, lienzos, cintas de hilo y ornamentos de iglesia.

78 Ibidem, págs. 125-127.

79 Martín Arrue, F., Historia del Alcázar de Toledo. Madrid 1889, pone en duda esta afirmación. Para una mayor información sobre el hecho, ver las págs. 136 y ss. de su obra. 
En 1813, realizado un inventario, se pudo comprobar que se habian salvado de la destrucción francesa 14 telares de estameña angosta, cuatro de ancho para paños y bayetones, cuatro lizos de dichos telares anchos, 12 telares de angosto, dos urdidores, un torno para torcer lana a la inglesa, 10 tornos de hilar estambres, un torno de enrolar y una prensa con su torno ${ }^{80}$.

Con estos escasos útiles se puso en funcionamiento la fábrica de lana en 1820 , en la que se manufacturaban paños catorceanos, estameñas finas y ordinarias, bayetas, bayetones, mantas, fajas y cobertores ordinarios, que por su buena calidad se vendían en la ciudad más fácilmente que los de las otras fábricas.

Como este instituto benéfico, modélico en su época, concebido con un nuevo y moderno patrón de asistencia caritativa, no pudo superar las diversas dificultades que se le presentaron a lo largo de su existencia, se vio abocado a su desaparición y con ella la de sus fábricas textiles, siendo asimilado en 1838 al Asilo de San Sebastián tras pagar a sus acreedores con las rentas y bienes que la quedaban, pasando el sobrante a engrosar el fondo del nuevo centro asistencial.

so A.D.P.T. Informe del Contador de la Casa de Caridad a instancias del Director de fecha 6 de agosto de 1813. Conjunto de documentos sin catalogar ni ordenar sobre la Casa de Caridad de Toledo. 